\title{
Identification of the non-tree vegetation of opada forest reserve for conservation
}

\author{
Ebiloma, S.O. 网
}

Received: 10.08.2019

Revised: 27.10 .2019

Accepted: 29.12.2019

\begin{abstract}
Objectives of study: to identify the non-tree vegetation of Opada Forest Reserve (OFR) and provide comprehensive vegetation data for monitoring, conservation and management of present biodiversity. OFR is about $215.76 \mathrm{~km}^{2}$ in size. Its map was gridded at an interval of one degree and each grid was $3.61 \mathrm{~km}^{2}$. Using a table of random numbers, ten of the grids were randomly selected. Within each grid, straight line transects of $2 \mathbf{k m}$ long were randomly laid using Global Positioning System, to locate transects in the right grids and prismatic compass to maintain straight transects, $25 \mathrm{~m} \times 25 \mathrm{~m}$ quadrates were taken at regular intervals of $500 \mathrm{~m}$. Each transect accommodated four quadrats which were 40 altogether. $1 \mathrm{~m}^{2}$ sub-plots were located at the four corners of the quadrates for identification and counting of species. There were 160 sub-plots for this assessment. About 48- grass species, 12- climbers, 37- herbs, 4- shrubs and 5- sedges were identified.
\end{abstract}

Key Words: Kogi State, Opada Forest Reserve, non-tree vegetation, shrub, grass, herb,

\section{Introduction}

Biodiversity refers to the total variety of living organisms (plants, animals, macro and micro organisms) that exist on planet earth. The biodiversity of a place is the totality of the genes, species and ecosystems that exist in that place (Ayodele and Lameed 1999). The manifestation of biodiversity is the biological resources (genes, species, organisms, ecosystems) and ecological processes of which they are part. Biodiversity is therefore considered at 3 major levels: Genetic diversity: This is the variety of genetic information contained in all of the individual plants, animals and micro-organisms occurring within populations of species. Simply it is the variation of genes within species and populations. -Species diversity: This is the variety of species or the living organisms. Species Richness: This refers to the total count/number of species in a defined area. Various indices are used including the Mangalet index and Menhink index. Species Abundance- This refers to the relative numbers among species. If all the species have the same equal abundance, this means that the variation is high hence high diversity, however if the one species is represented by 96

\section{Author's Address}

Department of Forestry and Wildlife, Faculty of Agriculture, Kogi State University, Anyigba, Kogi State, Nigeria.

E-mail.: ebilomastella@gmail.com individuals, whilst the rest are represented by 1 species each, this is low diversity. Taxonomic or phylogenetic diversity- This considers the genetic relationships between the different groups of species. The measures are based on analysis, resulting into a hierarchical classification representing the phylogenetic evolution of the taxa concerned. Ecosystem diversity: This relates to the variety of habitats, biotic communities and ecological processes in the biosphere. (Thecla 2009), Non-tree vegetation refers to all vegetation excluding trees. Especially shrubs, grasses, climbers, herbs, and sedge vegetation. Flora or plant diversity refers to the variety of plants that exist in the world. Different types of plants compete with plants and other organisms to survive in an ecosystem. Over time, they develop various characteristics to help them survive, which leads to plant diversity. The diversity of plant life exists for many reasons - a key factor being adaptive changes which allow different species to thrive in the many varied environments of the world. Plants have developed adaptations for different soil types, methods of pollination, daylight hours, temperature, altitude, competition with other plants. The list is endless; even two plants of the same species, separated by geography will have different genetic make-up. Diversity within any population is vital 
for that population's survival. The single most important fact about biological diversity is that it is not evenly distributed over the planet. This comes about quite simply because more species live in some places than others. This means that adverse changes in the environment will have a greater effect on biodiversity in some areas than in others. For example, the South American rainforests are particularly rich in terms of their biodiversity and their destruction is well publicized (Botanic Gardens Conservation International 2018).

The role that science can play in combating "Climate Change and its Impact" is to evolve ways for the conservation and management of the present biodiversity, especially biodiversity in the wild and make provisions or simulate ideas for meeting the needs of man for food, herbs and wood from outside the nature reserves such as forest, game reserves and national parks. As agreed to by Gerber (2010) in his article "conservation biology" and Okonkwo (2015), Discoveries of plants with good life supporting potentials, as well as advancements in health care deliveries depend on the availability of the right biodiversity resources in adequate amounts; conservation ensures sustainability of the wild species of these resources in continuity.

\section{Objectives of the study}

1. To identify the non-tree vegetation of Opada Forest Reserve (OFR) and

2. To provide comprehensive vegetation data (information) for effective conservation, monitoring and management of the flora of OFR.

\section{Material and Methods \\ Description of the study area}

Opada Forest Reserve is located in the eastern part of Kogi State, Nigeria. It has a total land area of $215.96 \mathrm{~km}^{2}$ (83.08sq miles). It lies between latitude $07^{0} 48^{\prime} 00.00^{\prime \prime} \mathrm{N}$ to Latitude $07^{0} 57^{\prime} 00.00^{\prime \prime} \mathrm{N}$ and Longitude $007^{0} 19^{\prime} 00.00^{\prime /} \mathrm{E}$ to Longitude $07^{0} 31^{\prime}$ $00.00^{\prime \prime} \mathrm{E}$. the forest is watered by the following six rivers; Egashi, Iyale, Oju ajoma-egbi, Emae, Inergia and Oje-ajokpa rivers. The forest reserve was set aside in accordance with section 36 of the forestry ordinance of Nigeria, it was surveyed in Feb, 1933, mapped in March, 1933 and approved $29^{\text {th }}$ January, 1934.

\section{Data collection}

Coordinates were taken round the boundaries of the reserve to assess the integrity of the size of the place with the aid of Global Positioning Systems (GPS). Data generated from GPS assessment were sent to a GIS station for the production of a map. The resulting map was gridded to obtain 41 plots, $25 \%$ (10 plots) were selected using a table of random numbers (Steel et al. 1997). Within each study plot, a straight line transect of $2 \mathrm{~km}$ long was randomly laid. The transect lines were established with the help of a GPS, in order to locate transects in the right sampling plots and a prismatic compass was used to maintain straight line transects. In the process of establishing the transect lines, tree trunks, low hanging branches and shrubs were tagged at $25 \mathrm{~m}$ interval along the transect lines, in areas where there were no vegetation to tag, stem cuttings were firmly dug into the soil at the point to be tagged, however some spots were too rocky to be dug, big rock pieces were piled and the peak of the pack tagged. Each tag was given a numerical number. This was necessary for easy identification of sampling routes. Tall grasses, shrubs and herbs along transect lines were simply reduced to ease movement in very bushy areas.

$25 \mathrm{~m} \times 25 \mathrm{~m}$ quadrates, were established at regular intervals of $500 \mathrm{~m}$ along the transect lines and alternately located on either side of the transect lines. Each transect accommodated four quadrants, there were 40 quadrates altogether. $1 \mathrm{~m}^{2}$ sub-plots were located at the four corners of each quadrant for the thorough identification and counting of grass species, there were 160 such sub-plots for grass assessment. Within each sub-plot, each nontree plant was thoroughly counted; samples of each plant species were uprooted and carefully preserved in poly-bags and brought to the office for identification. The figures obtained from this exercise within the sub-plots can be used by management to extrapolate the population of each identified species per hectare.

\section{Results and Discussion}

The results from the study are presented on tables 1 and 2. Table 1 revealed that 48-grass species were identified in the course of the studies from the 10 transects used for the study. 


\section{Identification of the non-tree vegetation of opada forest reserve}

Table 1: Grasses of Opada forest reserve study sites

\begin{tabular}{|c|c|c|c|c|c|c|c|c|c|c|c|c|}
\hline SN & SCIENTIFIC NAME & $\mathbf{T}_{1}$ & $\mathbf{T}_{2}$ & $\mathbf{T}_{3}$ & $\mathbf{T}_{4}$ & $\mathbf{T}_{5}$ & $T_{6}$ & $\mathbf{T}_{7}$ & $\mathbf{T}_{8}$ & $\mathbf{T}_{9}$ & $\mathbf{T}_{10}$ & Total \\
\hline 1. & Andropogon tectorum & 128 & 80 & & 50 & 130 & 7 & 360 & 230 & 164 & 772 & 1921 \\
\hline 2. & Andropogon gayanus & & & & & & & 10 & & & & 10 \\
\hline 3. & Afranum angustifolium & & & & & 79 & 35 & 16 & & & & 130 \\
\hline 4. & Aneilema aequinoctiale & & 10 & & & & & & & & & 10 \\
\hline 5. & Asystasia gangetica & & & 10 & 70 & & & 50 & & & 100 & 230 \\
\hline 6. & Borreria verticillata & & & & & & & & & & 15 & 15 \\
\hline 7. & Byrsocarpus coccineus & & & & 100 & & 20 & & & 20 & & 140 \\
\hline 8. & Cana Indica & & 76 & 22 & & & & & & & & 98 \\
\hline 9. & Cassia obtusifolia & & 3 & & & & & & & & & 3 \\
\hline 10. & Cissampelos mucronata & & & & & 40 & 20 & & & & & 60 \\
\hline 11. & Cymperus dilataus. & & 41 & & & & 12 & 25 & 80 & & & 158 \\
\hline 12. & Commelina benghalensis & & 104 & 65 & 70 & & & & & & & 239 \\
\hline 13. & Colocasia esculentum & & 20 & & & & & & & & & 20 \\
\hline 14. & Costus afer & & & & 50 & 263 & 7 & 27 & 85 & 212 & & 644 \\
\hline 15. & Crinum zeylanicus & & & & & 374 & 206 & 170 & & & & 750 \\
\hline 16. & Culcasia scandens & & & & 7 & & & & & & & 7 \\
\hline 17. & Cyperus esculentus & & 20 & & & 60 & & & & & & 80 \\
\hline 18. & Cynodon dactylon & & & 180 & & & & & & & & 180 \\
\hline 19. & Desmodium gengeticum & 6 & & & 62 & 54 & 32 & & & & & 154 \\
\hline 20. & Desmodium solicifolium & & 20 & & & 10 & 7 & & & & & 37 \\
\hline 21. & Dissotis irvingiana & & & 35 & 12 & & & & 30 & & & 77 \\
\hline 22. & Fimbristylis dichotoma & & & 177 & & & & & & & & 177 \\
\hline 23. & Gunterbergi nigritana & & & & 15 & & & & & & & 15 \\
\hline 24. & Imparata cylindrical & 14 & 10 & 12 & 20 & & 12 & & & & & 68 \\
\hline 25. & Impomoea involucrate & & & 15 & 40 & & & & & & & 55 \\
\hline 26. & Jussiaea decurrens & 10 & & & & & & & & & & 10 \\
\hline 27. & Mariscus alternifolius & & & & & 216 & 32 & 84 & 36 & 10 & & 378 \\
\hline 28. & Melanthera scandens & & & 5 & & & & & & & & 5 \\
\hline 29. & Mimosa Invisa & & 35 & & & & & & & & & 35 \\
\hline 30. & Monilia whitei & 30 & & & & & & & & & & 30 \\
\hline 31. & Oldenlandia alfinis & & & & 80 & & 10 & & & & & 90 \\
\hline 32. & Oplismenus hirtellus & & & & 80 & & & & & & & 80 \\
\hline 33. & Panicum brevifolium & & & & & 140 & 550 & & & & & 590 \\
\hline 34. & Panicum maximum & & & 40 & 29 & 140 & 10 & & & & & 219 \\
\hline 35. & Pennisetum bizantha & & & & & & & 20 & & & & 20 \\
\hline 36. & Pennisetum polystachyon & & & & 80 & 100 & 13 & & & & & 193 \\
\hline 37. & Phyllanthum amarus, & & & & & & & & & & 15 & 15 \\
\hline 38. & Piliostigma thonningii & 40 & & & & & & & & & & 40 \\
\hline 39. & Rottboellia cochinchinensis & 84 & 54 & & & 5 & 45 & 8 & 150 & & 170 & 516 \\
\hline 40. & Scleria boivinii & 40 & & & & & & & & & 30 & 70 \\
\hline 41. & Scleria naumanniana & & & 60 & & 110 & & & & & & 170 \\
\hline 42. & Stylosanthes erecta & & 30 & & & & & & & & & 30 \\
\hline 43. & Spigelia anthelinia & & & & 10 & 30 & & & & & & 40 \\
\hline 44. & Sesanum indicum & & & & & 50 & & & & & & 50 \\
\hline 45. & Seteria anceps & & & & & & & & & & 95 & 95 \\
\hline 46. & Schizachyrium sanguineum & & & & & 100 & & & & & 105 & 205 \\
\hline 47. & Tephrosia bracteolate & & 40 & & 200 & & & & & & & 240 \\
\hline 48. & Vigna pubigura & & & 40 & 10 & 35 & & & & & & 85 \\
\hline
\end{tabular}


Ebiloma Stella

Table 2: Climber, herb, shrub, and sedge vegetation of Opada forest reserve study sites

\begin{tabular}{|c|c|c|c|c|c|c|c|c|c|c|c|c|c|}
\hline $\mathrm{SN}$ & Name of plant & Total & Typess & $\mathrm{T}_{1}$ & $\mathrm{~T}_{2}$ & $\mathrm{~T}_{3}$ & $\mathrm{~T}_{4}$ & $\mathrm{~T}_{5}$ & $\mathrm{~T}_{6}$ & $\mathrm{~T}_{7}$ & $\mathrm{~T}_{8}$ & $\mathrm{~T}_{9}$ & $\mathrm{~T}_{10}$ \\
\hline 1. & $\begin{array}{l}\text { Aframum } \\
\text { Angustifoliu }\end{array}$ & 127 & Herb & & & & 16 & 95 & 16 & & & & \\
\hline 2. & $\begin{array}{l}\text { Asystasia } \\
\text { gagetica }\end{array}$ & 230 & Herb & & & 10 & 70 & & & 50 & & & 100 \\
\hline 3. & $\begin{array}{l}\text { Aneilema } \\
\text { Aeqinoctiale }\end{array}$ & 10 & Herb & 10 & & & & & & & & & \\
\hline 4. & Cana indica & 85 & Herb & 63 & 22 & & & & & & & & \\
\hline 5. & $\begin{array}{l}\text { Colocasia } \\
\text { Esculentum }\end{array}$ & 20 & Climber & 20 & & & & & & & & & \\
\hline 6. & $\begin{array}{l}\text { Commelina } \\
\text { Benghalensis }\end{array}$ & 259 & Herb & 104 & 65 & 90 & & & & & & & \\
\hline 7. & $\begin{array}{l}\text { Commelina } \\
\text { Diffusa }\end{array}$ & 451 & Herb & 158 & 23 & & 45 & 106 & 23 & 8 & 30 & & 58 \\
\hline 8. & $\begin{array}{l}\text { Crinum } \\
\text { Zeylanicus }\end{array}$ & 754 & Herb & & & & 378 & 206 & 170 & & & & \\
\hline 9. & $\begin{array}{l}\text { Cissampelos } \\
\text { Mucronata }\end{array}$ & 60 & Climber & & & & 40 & 20 & & & & & \\
\hline 10. & Cissus populnea & 669 & Climber & & 15 & 70 & 265 & 7 & 17 & 85 & 212 & & \\
\hline 11. & $\begin{array}{l}\text { Cymperus } \\
\text { Dilatatus }\end{array}$ & 158 & Sedge & 41 & & & & 12 & 25 & 80 & & & \\
\hline 12. & $\begin{array}{l}\text { Cymperus } \\
\text { Esculentus }\end{array}$ & 80 & Sedge & & 20 & & 60 & & & & & & \\
\hline 13. & $\begin{array}{l}\text { Culcasia } \\
\text { scandens }\end{array}$ & 7 & Herb & & & 7 & & & & & & & \\
\hline 14. & $\begin{array}{l}\text { Desmodium } \\
\text { Gangeticum }\end{array}$ & 202 & Herb & 6 & & 112 & 54 & 30 & & & & & \\
\hline 15. & $\begin{array}{l}\text { Desmodium } \\
\text { Salicifolium } \\
\end{array}$ & 17 & Herb & & & & 10 & 7 & & & & & \\
\hline 16. & $\begin{array}{l}\text { Dioscorea } \\
\text { Bulbifera }\end{array}$ & 982 & Herb & & 50 & & 250 & & 116 & 107 & 300 & & 159 \\
\hline 17. & $\begin{array}{l}\text { Dissotis } \\
\text { Irvingiana }\end{array}$ & 77 & Herb & 35 & 12 & & & & 30 & & & & \\
\hline 18. & $\begin{array}{l}\text { Fimbristylis } \\
\text { Dichotoma }\end{array}$ & 117 & Herb & & 117 & & & & & & & & \\
\hline 19. & $\begin{array}{l}\text { Guntenbergia } \\
\text { Nigritana }\end{array}$ & 15 & Herb & & & 15 & & & & & & & \\
\hline 20. & $\begin{array}{l}\text { Impomoea } \\
\text { Involucrate }\end{array}$ & 55 & Climber & & & & 15 & 40 & & & & & \\
\hline 21. & $\begin{array}{l}\text { Jussiaea } \\
\text { decurrens }\end{array}$ & 10 & Herb & 10 & & & & & & & & & \\
\hline 22. & $\begin{array}{l}\text { Mariscus } \\
\text { alternitolius }\end{array}$ & 384 & Sedge & & & & 6 & 216 & 32 & 84 & 36 & 10 & \\
\hline 23. & $\begin{array}{l}\text { Melanthera } \\
\text { Scandens }\end{array}$ & 5 & Herb & & & 5 & & & & & & & \\
\hline 24. & Mimosa invisa & 35 & Shrub & & 35 & & & & & & & & \\
\hline 25. & $\begin{array}{l}\text { Oldenlandia } \\
\text { Affinis }\end{array}$ & 90 & Herb & & & & 80 & & 10 & & & & \\
\hline 26. & $\begin{array}{l}\text { Phyllanthus } \\
\text { Amarus }\end{array}$ & 15 & Herb & & & & & & & & & & 15 \\
\hline 27. & Scleria boivinii & 180 & Sedge & 40 & & 110 & & & & & & & 30 \\
\hline 28. & $\begin{array}{l}\text { Scleria } \\
\text { Naumanniana }\end{array}$ & 110 & Sedge & 60 & & 50 & & & & & & & \\
\hline 29. & $\begin{array}{l}\text { Sesamum } \\
\text { indicum }\end{array}$ & 95 & Herb & & & & & & & & & & 95 \\
\hline 30. & Stylosanthes & 39 & Herb & & 30 & & & & & & & & \\
\hline
\end{tabular}


Identification of the non-tree vegetation of opada forest reserve

\begin{tabular}{|c|c|c|c|c|c|c|c|c|c|c|c|c|c|}
\hline 31. & $\begin{array}{l}\text { Spigelia } \\
\text { anthelmia }\end{array}$ & 40 & Herb & & & & 10 & 30 & & & & & \\
\hline 32. & $\begin{array}{l}\text { Tephrosia } \\
\text { Bracteolate }\end{array}$ & 240 & Shrub & & 40 & & 200 & & & & & & \\
\hline 33. & Vigna gracils & 75 & Herb & & 15 & 30 & & 30 & & & & & \\
\hline 34 & $\begin{array}{l}\text { Asparagus } \\
\text { africanus } \\
\text { Ixnn \& A. Pauli }\end{array}$ & 109 & Climber & & & & 1 & 35 & 63 & & 10 & & \\
\hline 35 & $\begin{array}{l}\text { Byrso carpus } \\
\text { Coccineus } \\
\text { (schum \& Thinn) }\end{array}$ & 160 & Herb & & & & 100 & & 30 & & & 30 & \\
\hline 36 & $\begin{array}{l}\text { Choclospernum } \\
\text { Tictorium }\end{array}$ & 4 & Herb & & 3 & & 1 & & & & & & \\
\hline 37 & $\begin{array}{l}\text { Combretum } \\
\text { molle } \\
\text { (R.Br.Ex G.Don) }\end{array}$ & 17 & Climber & 5 & 10 & & & & & & & & 2 \\
\hline 38 & $\begin{array}{l}\text { Desmodium } \\
\text { solicifolium } \\
\text { (Poir)DC }\end{array}$ & 27 & Herb & & & & 10 & 7 & & & 10 & & \\
\hline 39 & $\begin{array}{l}\text { Desmodium } \\
\text { velutinum } D C\end{array}$ & 135 & Herb & & & & 35 & & 40 & & & 60 & \\
\hline 40 & $\begin{array}{l}\text { Eriosema } \\
\text { elomeratum } \\
\text { Hook.F. }\end{array}$ & 5 & Herb & 5 & & & & & & & & & \\
\hline 41 & $\begin{array}{l}\text { Gongronema } \\
\text { Latifolium }\end{array}$ & 8 & Climber & 5 & & 3 & & & & & & & \\
\hline 42 & $\begin{array}{l}\text { Gardenia } \\
\text { terifolia schum \& } \\
\text { Thinn }\end{array}$ & 15 & Shrub & 1 & & & & 1 & 11 & 1 & 1 & & \\
\hline 43 & $\begin{array}{l}\text { Icacina terifolia } \\
\text { olie }\end{array}$ & 110 & Herb & & & 110 & & & & & & & \\
\hline 44 & Lantana spp & 66 & Herb & & 15 & & & 21 & & & 30 & & \\
\hline 45 & $\begin{array}{l}\text { Mucuna pruriens } \\
\text { DC }\end{array}$ & 10 & Climber & 10 & & & & & & & & & \\
\hline 46 & $\begin{array}{l}\text { Nelsonia } \\
\text { campestris R.Br. }\end{array}$ & 100 & Herb & & & & & & & & & & 100 \\
\hline 47 & Olax viridis & 102 & Herb & & & & & & & & & 101 & 1 \\
\hline 48 & $\begin{array}{l}\text { Pipper } \\
\text { guineensis }\end{array}$ & 2 & Herb & 1 & & 1 & & & & & & & \\
\hline 49 & $\begin{array}{l}\text { Palisota hirsute } \\
\text { K.Schum }\end{array}$ & 65 & Herb & 20 & & & 35 & & & 10 & & & \\
\hline 50 & $\begin{array}{l}\text { Paulinia pinattu. } \\
\text { Linn }\end{array}$ & 95 & Climber & & & & & & & & & 40 & 55 \\
\hline 51 & $\begin{array}{l}\text { Sarcoce phallus } \\
\text { latifolius (S.M) } \\
\text { Bruce }\end{array}$ & 13 & Shrub & & & & 2 & & 1 & & & 10 & \\
\hline 52 & $\begin{array}{l}\text { Siphonochilius } \\
\text { aethiopicus }\end{array}$ & 89 & Herb & 20 & & 5 & & & & & 64 & & \\
\hline 53 & $\begin{array}{l}\text { Sidalinifolia juss } \\
\text { ex cav. }\end{array}$ & 59 & Herb & 20 & & & 12 & & 27 & & & & \\
\hline 54 & Tregia spp pax & 44 & Herb & 17 & & 3 & & 22 & & & & & \\
\hline 55 & $\begin{array}{l}\text { Urena lobata } \\
\text { Linn }\end{array}$ & 180 & Herb & & 40 & & & & & 100 & & 40 & \\
\hline 56 & Uvaria chamae & 7 & Climber & & & & & & & 7 & & & \\
\hline
\end{tabular}




\begin{tabular}{|c|c|c|c|c|c|c|c|c|c|c|c|c|c|}
\hline 57 & Vigna gracilis & 198 & & 15 & 30 & & 30 & & & & & 24 & 99 \\
\hline 58 & $\begin{array}{l}\text { Wissudula } \\
\text { spp.Linn }\end{array}$ & 30 & Herb & & & & & & 20 & 10 & & & \\
\hline SN & Name of plant & Total & Typess & $\mathrm{T}_{1}$ & $\mathrm{~T}_{2}$ & $\mathrm{~T}_{3}$ & $\mathrm{~T}_{4}$ & $\mathrm{~T}_{5}$ & $\mathrm{~T}_{6}$ & $\mathrm{~T}_{7}$ & $\mathrm{~T}_{8}$ & $\mathrm{~T}_{9}$ & $\mathrm{~T}_{10}$ \\
\hline 34. & $\begin{array}{l}\text { Aframum } \\
\text { Angustifoliu }\end{array}$ & 127 & Herb & & & & 16 & 95 & 16 & & & & \\
\hline
\end{tabular}

Source: Field survey. Where: $T_{1-} T_{10}$ refers to transects 1- 10.

In the course of this study, 12- climbers, 37- herbs, 4- shrubs and 5- sedges were identified as presented on table 2 .

The above vegetation lists were compiled with the aid of important plant identification aids "Some changes and corrections..." (Lowe and Sholade 1990). The useful plants of West tropical Africa (Daziel 1953), Flora of West African trees volume 1 part one and two and volume 2 (Hutchinson and Daziel 1954). A hand book of West African weeds (Okeziel et al. 1998). The flora of Nigeria: grasses (Lowe 1989), Traditional medicine and Pharmacopoeia (Mashana et al. 2000). There is more to non-tree forest vegetation than meets the eyes, important products derived from non-tree forest vegetation abound and include: Food products, edible fruits, Vegetables, Spices, condiments and herbs. Industrial plant oils and waxes, plant gums, natural plant pigments, seeds, fibers and rattern, vegetable tanning materials, essential oils, insecticides/herbicides and medicinal plants. In a study by Lorena (2009) to access the role of plant interactions in the restoration of degraded ecosystem a meta analysis across lifeforma and ecosystems. The life-form of the interacting species, particularly of neighbours, largely influenced the interaction outcome. Herbs had strong negative effects, especially on other herb species, whereas shrubs had large facilitative effects, especially on trees. Semiarid and tropical systems showed in general more positive neighbour effects than wetlands and particularly mesic temperate systems, where negative interactions predominated. However, these results were largely influenced by the over-representation of herb species in wetlands and temperate habitats, survival facilitation being found in all systems when only woody species were considered. Pre-existing vegetation can have large impacts on species establishment in degraded habitats. $\mathrm{He}$ also observed that inhibition predominates in herbaceous communities typical of early- successional stages, whereas facilitation prevails in communities dominated by shrubs and trees, whereas restoring herbaceous communities seems largely reliable on removal techniques, augmenting populations of nurse shrubs and trees should be considered a promising strategy for restoring woody late-succession communities.

The grass species are working hard to keep us cool, soak up carbon, capture particulates in the air, produce oxygen, capture rain water and reduce runoff (Lorena, 2009) which results in land degradation like erosion. However, keeping lawns green in Southern California is said to increase greenhouse gas emissions, rather than absorbing them, the problem is all the emissions needed to keep the lawns healthy: mowing, leaf-blowing, production of fertilizer all these add up to four times the amount of greenhouse gas that the grass can store in its soil as carbon. Spreading fertilizer causes soil beneath the grass to release nitrous oxide, and while its warming effects are dwarfed by those of carbon dioxide, it is, 300 times more potent as a greenhouse gas (Brennan, 2010; Ensarbete, 2015). "An athletic field gets tilled every year, over a 35-year timescale; there's no net storage of carbon." (Townsend 2010). While these findings hold true for Southern California, they might not for parts of the world with enough rainfall to keep lawns green without watering - "in a place where lawns grow naturally, where you don't have to irrigate or fertilize them, and you don't have to mow them all the time." Furthermore, cattle emit huge amounts of methane, especially if corn-fed. Grass that may help tackle global warming by cutting the level of methane given off by cows is being developed reports the latest issue of the Society of Chemical Industry (2008) Timothy, (2009). Methane is denser than and 23 times more effective as a global warming agent than carbon dioxide" (Townsend 2010). Grasses can sequester huge amounts of carbon annually, especially when grazing practices include high density, short-term exposure efforts with the cattle eating the grasses 
down and moving on to let the grasses grow back. This sustainable grazing technique causes some root shedding below the soil line, leaving lots of organic matter, and thus, carbon. On just one acre of biologically healthy grassland soil, there can be between $0.5-1.5$ tons of carbon deposited in the soil annually. This is equivalent to taking up to 5.5 tons of $\mathrm{CO}_{2}$ out of the atmosphere and sinking it into an acre of soil. While this impressive level of carbon sequestration is impossible in the high desert with little rainfall, it is absolutely viable where there is rain or available water to grow pasture. With proper management, ruminants can once again contribute to the life and water cycle supporting ecology of our biological system. This amazing ecological interaction on 11 billion global acres of grazed land would equate to sequestering $60 \%$ of human-caused $\mathrm{CO}_{2}$

\section{Conclusion}

The non-tree forest products are of extreme importance in today's world economy considering the long list of products and benefits derivable from them. Except their use is properly studied and known abuse, indiscriminate utilization of the wild species and possible extinction is inevitable.

\section{Recommendation}

Information on the possible contribution in combating "Climate Change and its Impact on Africa" by this group of plant species that are so abundant in the environment is scanty and so needs scientific attention and results made public. Even if the use of some of them is not currently known their conservation should of a necessity be promoted pending when knowledge gets to that junction. Opada Forest Reserve till date is a natural forest, even with serious illegal exploitations there has never been any form of enrichment planting or restocking with plants or animals but for external boundary maintenance. Pressure from conservationist and international public opinion is strongly requested to prevail on the government of Nigeria to upgrade Opada forest reserve to a game reserve or better still to a national park so as to ensure sustainability of the reserve for posterity in perpetuity.

\section{References}

Ayodele, I.A., Lameed, G.A. 1999. THE current status of Biodiversity management. Essentials of Biodiversity Management. Power house press and publishers. Ibadan. $74 \mathrm{pp}$.

Botanic Gardens Conservation International 2018. Plant Diversity

http://www.bgci.org/cultivate/plant_diversity [accessed 18.03.18]

Brennan, P. 2010. Greenhouse grass: Do lawns make global warming worse?

http://greenoc.freedomblogging.com/2010/01/19/greenhousegrass-do-lawns- make-global-warming-worse/18809/ [accessed 17.03.18].

Daiziel, J.M. 1953. The useful plants of West Tropical Africa. Britain. 610pp.

Ensarbete, E. 2015. Energy use and carbon footprint from lawn management. A case study in the Uppsala region of Sweden. $\quad$ http://www.wprogram.nu/filer/exjobb/Therese Wesstrom.pdf. [accessed 17.03.18].

Gerber, L. 2010 Conservation Biology. Nature Education Knowledge. 3(10):14

Hutchson, J. and Daiziel, J.M. 1954. Flora of West Tropical Africa. Second edition. 11(1): 544.

Lorena Gómez-Aparicio 2009. The role of plant interactions in the restoration of degraded ecosystem a meta analysis across life-forma and ecosystems. Journal of Ecology. 97: 6

Lowe, J. 1989. The flora of Nigeria: Grasses. Second edition. Ibadan University press. 326pp.

Lowe, J. and Soladoye, M.O. 1990. Some changes and corrections to names of Nigerian plants. Nigerian journal of Botany, 3: 1-24.

Mashana, N.R., Abbiw, D.K., Addae-Mensah, I., Adjanouhoun, E., Ahyi, M.R.A., Ekpere, J.A., EnowDrock, E.G., Gbile, Z.O., Naomesi, G.K., Odei, M.A., Odunlami, H., Oteng-Yeboah, A.A., Sarpong, K.S.A. and Takie, A.N. 2000. Traditional medicine and pharmacopoeia. Contribution to the revision of ethnobotanical and floristic studies in Ghana. Accra. 920pp.

Okezie, I.A. and Agyakwa, C.W. 1998. A hand book of West African weeds. International institute of Tropical Agriculture. Second edition. Ibadan. 565pp.

Okonkwo, T. 2015. "Sustainable development and protection of endangered species fauna and flora in the wild in 


\section{Ebiloma Stella}

developing countries", International Journal Development and Sustainability, 4(11):1086-1115.

Steel, R.G.D., Torrie, H.J. and Dickek, A.D. 1997. Principles and Procedures of Statistics. A Biometrical approach. New York. $666 \mathrm{pp}$

Thecla, M. and Mutia 2009. Biodiversity Conservation. https://orkustofnun.is/gogn/unu-gtp-sc/UNU-GTP-SC-100805b.pdf (assessed 08/06/2018) of Townsend, S. 2010. Lawns may contribute to global warming. http://www.csmonitor.com/Environment/Bright-

Green/2010/0122/Lawns-may-contribute-to-globalwarming

Timothy, J. L. 2009. In Defense of the Cow: How Eating Meat Could Help Slow Climate Change Chemistry, 126: 1122 1126. 